\title{
DISSOLVED INORGANIC CARBON AND METABOLISM OF AN EUTROPHIC LACUSTRINE SYSTEM: VARIATIONS FROM A 36-HOURS STUDY
}

\author{
PEDROSA, P. and REZENDE, C. E. \\ Laboratório de Ciências Ambientais (LCA), Centro de Biociências e Biotecnologia (CBB), Universidade Estadual \\ do Norte Fluminense (UENF), Av. Alberto Lamego, 2.000, Horto, CEP 28015-620, Campos, RJ, Brazil \\ Correspondence to: Paulo Pedrosa, Laboratório de Ciências Ambientais (LCA), Centro de Biociências e \\ Biotecnologia (CBB), Universidade Estadual do Norte Fluminense (UENF), Av. Alberto Lamego, 2.000, Horto, \\ CEP 28015-620, Campos, RJ, Brazil, e-mail: pedrosa@cbb.uenf.br \\ Received September 14, 1999 - Accepted January 31, 2000 - Distributed November 30, 2000
}

(With 3 figures)

\begin{abstract}
Based on variations of pelagial dissolved inorganic carbon (DIC) concentrations this article provides estimations of net primary productivity and net mineralization - net carbon metabolism - in Cima Lake (Rio de Janeiro State). DIC concentrations varied from 203 to $773 \mu \mathrm{mol} \mathrm{L}^{-1}$ and $\% \mathrm{CO}_{2 \text { (aq) }}$ (saturation) from 339 to 4,901 . Net carbon metabolism per light/dark periods from the 36 hours of study ranged, respectively, from -556 to $503 \mathrm{mmol}$ DIC $\mathrm{m}^{-2} 12 \mathrm{~h}^{-1}$. Marked variations in daily net carbon metabolism of the lake were also observed. The values ranged from -25 to $-194 \mathrm{mmol}$ DIC m${ }^{-2} \mathrm{day}^{-1}$. The findings were discussed as indicators of dynamic biological behavior toward production or mineralization of organic matter in the system. And, the system seemed to shift from heterotrophy to autotrophy. Additionally, in the light of our results we emphasize the axial influence of both sampling strategy and treatment of scientific data for a characterization/interpretation of aquatic systems' metabolism.
\end{abstract}

Key words: DIC, carbon metabolism, net primary productivity, mineralization, eutrophic lake.

\section{RESUMO}

Carbono inorgânico dissolvido e metabolismo de um sistema lacustre eutrófico: Variações derivadas de um estudo de 36 horas

Este artigo fornece estimativas de produtividade primária e mineralização líquidas - metabolismo líquido do carbono - ocorrentes na Lagoa de Cima (Estado do Rio de Janeiro), em função das variações das concentrações de carbono inorgânico dissolvido (CID) no meio pelágico. As concentrações de CID abrangeram o intervalo entre 203 e $773 \mu \mathrm{mol} \mathrm{L}^{-1}$ e o $\% \mathrm{CO}_{\text {2(aq) }}$ (saturação) entre 339 e 4.901. O metabolismo líquido do carbono por período individual (claro/escuro) variou entre -556 e $503 \mathrm{mmol}$ DIC m ${ }^{-2} 12 \mathrm{~h}^{-1}$ no intervalo de 36 horas de estudo. Também foram observadas variações acentuadas no metabolismo líquido do carbono para ciclos de 24 horas. Os valores estenderam-se entre -25 e 194 mmol DIC m ${ }^{-2}$ day $^{-1}$. Os resultados são discutidos como indicadores de um comportamento biológico dinâmico direcionado à produção ou mineralização da matéria orgânica no sistema. E o sistema pareceu deslocar-se de uma função heterotrófica para autotrófica. Em adição, orientados pelos resultados obtidos, enfatizamos a importância axial da estratégia de amostragem e do tratamento científico de dados obtidos para a caracterização/interpretação do metabolismo de sistemas aquáticos.

Palavras-chave: CID, metabolismo do carbono, produtividade primária líquida, mineralização, lagoa eutrófica. 


\section{INTRODUCTION}

Dissolved inorganic carbon (DIC) exists in aquatic systems as unionized carbon dioxide, whether present as $\mathrm{H}_{2} \mathrm{CO}_{3}$ or as $\mathrm{CO}_{2}$, and ionized species as $\mathrm{HCO}_{3}^{-}$and $\mathrm{CO}_{3}{ }^{2-}$. DIC is by far the greatest 'active' carbon reservoir at the Earth's surface. It has a mass equivalent to almost eight times the total comprised by other carbon reservoirs like atmospheric $\mathrm{CO}_{2}$, land plants, seawater dissolved organic carbon, soil humus, soil carbonate and surface marine sediment organic carbon (Hedges, 1992). This is relevant because directly or indirectly the entire biosphere depends on inorganic carbon as the major nutrient for primary producers.

In aquatic systems physical, chemical and biological processes influence inorganic carbon concentration. Atmospheric carbon dioxide concentrations, wind speed, $\mathrm{pH}$, salinity, carbonates, depth, temperature, alkalinity, respiration, and photosynthesis are factors that typically affect DIC concentrations. Thus, diel variations in DIC concentrations may be used for evaluations of net biological activity of aquatic communities only after corrections for physical and chemical processes.

From these interactions DIC has been corelated to a variety of environmental issues, such as: (i) the recent (post-Industrial Revolution) increasing in atmospheric $\mathrm{CO}_{2}$ levels (from ca. 275 to 355 ppmv), which may affect the current planetary feedback mechanisms (Falkowski, 1994), (ii) vertical fluxes of carbon from trophogenic to tropholitic zone (biological pump) (Hansell et al., 1997) and, (iii) metabolism of aquatic systems (autotrophic-production vs. heterotrophic-mineralization), which is ecologically related to their structure and function (Carmouze et al., 1991, 1994; del Giorgio \& Peters, 1993; Souza \& Couto, 1999). Other issues related to DIC are the influence of $p \mathrm{CO}_{2 \text { (aq) }}$ on the stable carbon isotopic fractionation (e.g. $\delta^{13} \mathrm{C}$ ) by microalgae (Wainright \& Fry, 1994), and, in a minor extent, $\mathrm{CO}_{2(\mathrm{aq})}$ as limiting factor of microalgae growth (Riebesell et al., 1993; Raven, 1993).

Based on variations of DIC concentrations this article provides estimations of net primary production and mineralization of carbon - net carbon metabolism - in Cima Lake (Rio de Janeiro State). This is the first assessment on carbon metabolism of Cima Lake. Variations on daily net car- bon metabolism of Cima Lake are pointed out and interpreted as a clear evidence of an unstable situation in the aquatic environment. The findings are discussed as indicators of dynamic biological behavior toward production or mineralization of organic matter in the system. Additionally, in the light of our results we emphasize the axial influence of both sampling strategy and treatment of scientific data for a characterization/interpretation of aquatic systems' metabolism.

\section{MATERIAL AND METHODS}

\section{Study area and site samplings}

Cima Lake is located in the Municipality of

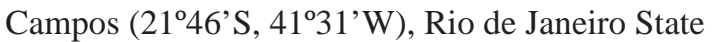
(Brazil). The lacustrine system contributes economically to the region either as a fishing source or as touristic/recreational site. It has been target of hydrobiological, geochemical and ecophysiological studies (PRO-AGRO, 1975; Huszar \& Silva, 1992; Almeida, 1998; Calasans, 1998; Andrade et al., 1998; Pedrosa et al., 1999). Fluvial processes from the Quaternary period at the Holocene epoch formed the lake (Lamego, 1945). The lake is a medium $\left(13.5 \mathrm{~km}^{2}\right)$, freshwater $\left(<50 \mu \mathrm{S} \mathrm{cm}^{-1}\right)$, shallow (maximum depth frequently $<4.0$ meters) and eutrophic phytoplankton based-system [average Chl $a>30 \mu \mathrm{g} \mathrm{L}^{-1}$ (center of the Lake)]. The water column is typically nonstratified (holomitic/polimitic lake). Macrophytes are mostly limited to the littoral zone, especially close to the mouth of Imbé and Urubu streams. The water is very soft, and there is no carbonate in the bottom sediments. Sugar cane crops, patches of secondary forest and pasture domains surround the lacustrine system. The watershed is of gneissic-granitic origin followed by Quaternary plains of sedimentary nature, and its area accounts for $710 \mathrm{~km}^{2}$. Imbé stream provides most $(\sim 100 \%)$ of the water inflow to the lake and the lake water outflows through the Ururaí channel (Fig. 1). Three sites were considered for the present study and their locations are presented in Fig. 1.

\section{Sampling and analytical procedures}

This study covered 36 hours with two dark periods (nights) and one light period (day) - from 5:30 p.m. to 5:30 a.m. - on March $5^{\text {th }}, 6^{\text {th }}$ and $7^{\text {th }}$, 1997. The sequence of sampling followed the order: site $1 \rightarrow$ site $3 \rightarrow$ site 2 (Fig. 1). 


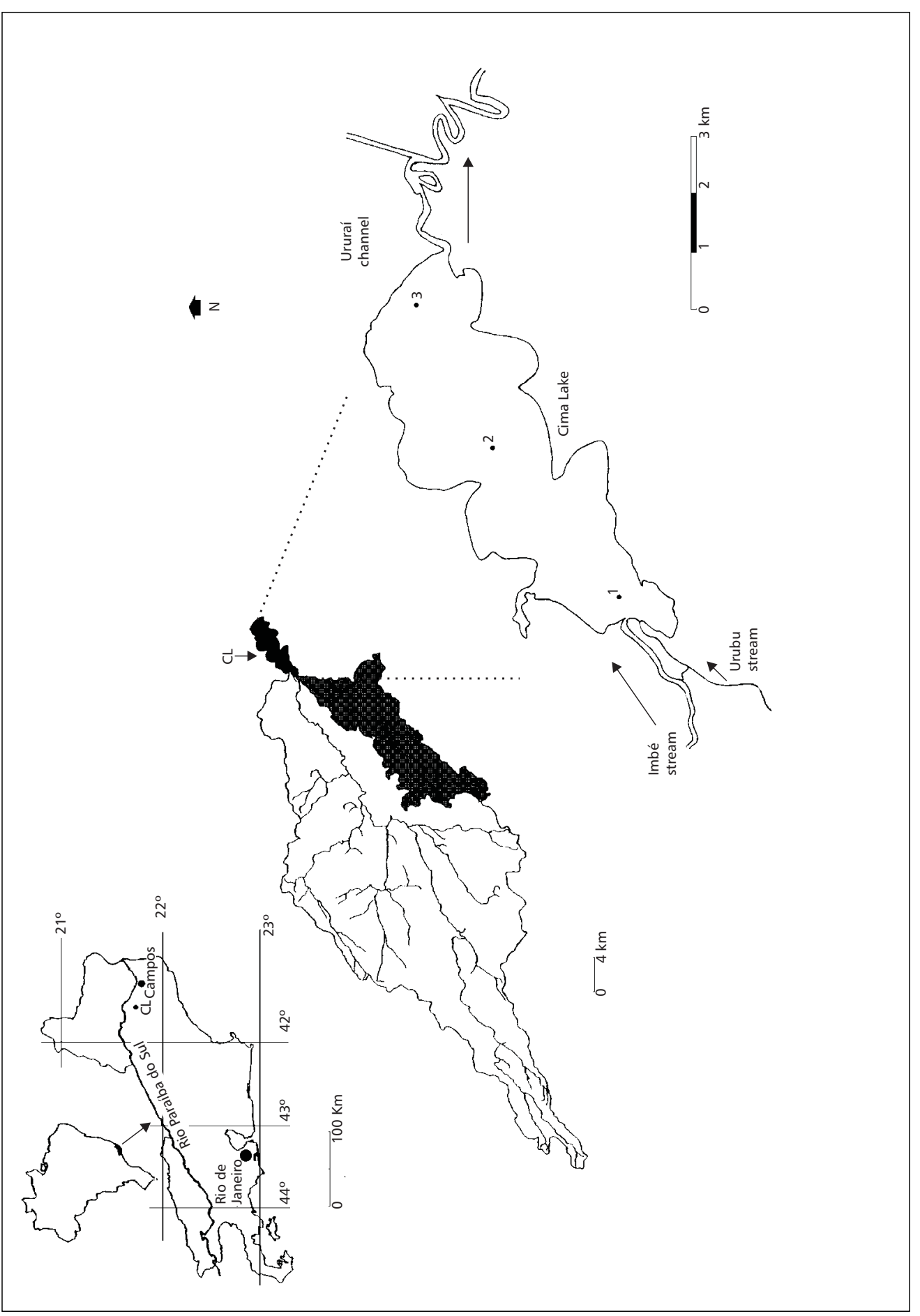

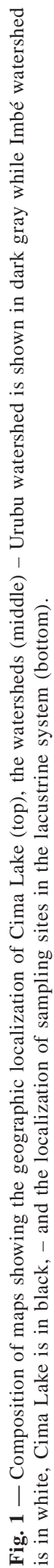


The mean time for concluding each set of sampling (all the three sites) was 40 minutes. The depth at sites 1, 2 and 3 was 2.8, 4.1 and 3.4 meters, respectively. Water samples were collected with a van Dorn bottle at sub surface depths $(\sim 0.20$ $\mathrm{m})$. Polyethylene and oxygen bottles were gentle filled from the bottom, overflowing the water for at least a half of their volumes and closed with no head-space or bubble air. The former were kept in a cool and dark ambient (in an icebox) and the latter were kept immersed in water from the lake (also in an icebox) until the moment of analyses. The analyzes were performed immediately after each set of sampling. Dissolved oxygen (DO) was determined according to Winkler method (Wetzel \& Likens, 1991) with a semi-automatic titration system (Hydro-Bios Kiel). Temperature and $\mathrm{pH}$ were measured with portable meters (thermometer and Digimed DMPH-3 pHmeter). Total alkalinity was determined through an automated acidimetric titration system (Mettler DL-21 titrator) with $0.01 \mathrm{~N} \mathrm{HCl}$ as the acid solution. For every pair of consecutive samples (two consecutive samplings from an specific site) total alkalinity was averaged as suggested by Carmouze (1994). Total DIC concentrations, $\mathrm{CO}_{2} \%$ saturation and net biological activities were determined from temperature, $\mathrm{pH}$, and averaged total alkalinity (as previously described) by using a set of algorithms ("CARBDOCE", "CO 2 EQ2" and "BIOFLUX"; Carmouze, 1994). The values of wind speed used to calculate gas exchange coefficients were from the meteorological campus of the Universidade Federal Rural do Rio de Janeiro (Campos, RJ), which is $\sim 10 \mathrm{~km}$ away from the study area. For every site a total of thirteen samples $(n=13)$ were collected. Sample analyses were run in duplicate or triplicate and the analytical coefficient of variation was consistently lower than $5 \%$.

\section{RESULTS AND DISCUSSION}

\section{Metabolic status of the lake - indicators}

The lake was characterized by low values of alkalinity, varying from 147 to $301 \mu \mathrm{Eq} \mathrm{L} \mathrm{L}^{-1}$; slightly acid to neutral $\mathrm{pH}$, ranging from 6.03 to 7.03 ; dissolved oxygen (DO) ranging from 128 to 248 $\mu \mathrm{mol} \mathrm{L}{ }^{-1}$, and DIC varying from 203 to $773 \mu \mathrm{mol}$ $\mathrm{L}^{-1}$ (Table 1). Water temperature varied from 27 to $29^{\circ} \mathrm{C}$ (Table 1) and diurnal curve paralleled those of $\mathrm{pH}$ (Spearman correlation $\left(\mathrm{r}_{s}\right)=0.433, \mathrm{n}=39$,
$P<0.01)$ and DO $\left(\mathrm{r}_{s}=0.449, \mathrm{n}=39, P<0.01\right)$. The correlation between $\mathrm{DO}$ and $\mathrm{pH}$ was even more evident $\left(r_{s}=0.904, \mathrm{n}=39, P<0.01\right)$. These data suggest that primary productivity, or mineralization, or both, were affected by diurnal variation of temperature and light. Light availability and increased temperature are physical factors that typically may give a higher photosynthetic rate (Raven, 1994). In addition, the horizontal distribution of both DO$\mathrm{pH}$ and DIC-\% $\mathrm{CO}_{2(\mathrm{aq})}$ followed an opposite gradient of concentrations. This is expected because oxygen and carbon dioxide are, at least in part, complementary tracers of metabolic activities (Carmouze, 1994). By mineralization (e.g. bacterial respiration) water $\mathrm{pH}$ tend to decrease with the increase of inorganic carbon concentrations. On the other hand, phototrophic carbon dioxide fixation often lead to an increase of $\mathrm{pH}$ and $\mathrm{DO}$ as a result of oxygenic photosynthesis (Wetzel \& Likens, 1991). Therefore, while DO and $\mathrm{pH}$ tended to increase from site 1 to site 2 and/or 3, DIC and $\% \mathrm{CO}_{2(\text { aq) }}$ tended to decrease. The $\mathrm{CO}_{2}$ saturation (\%) varied greatly, from 665 to 4,901, from 385 to 1,749 , and from 339 to 1,656 in sites 1,2 and 3 respectively (Table 1). Despite these differences all values stated a condition of carbon dioxide supersaturation in the lake, which is an indication of heterotrophy or net respiration in the lake.

\section{Carbon metabolism - variations in the lacustrine system}

At first glance, DIC data suggest that heterotrophic activity was dominant in Cima Lake and, consequently, that the lacustrine system functioned as a net source of inorganic carbon. In the dark periods there was, indeed, a net production of DIC (Table 2). However, the arithmetic mean of combined periods from Table 2 [dark/light from days 5 and 6 ('combination 1'), and light/dark from days 6 and 7 ('combination 2')] showed a net primary productivity in the lake, irrespective to the site considered. Therefore, the system had a net consume of DIC from 56 (site 1) to $109 \mathrm{mmol} \mathrm{m}^{-2}$ day $^{-1}$ (site 2 ), which corresponds to a production of organic carbon of 0.7 and $1.3 \mathrm{~g} \mathrm{C} \mathrm{m}^{-2} \mathrm{day}^{-1}$, respectively (Fig. 2). Autotrophy in the lake was also confirmed by individual combinations of dark/light ('combination 1') and light/dark ('combination 2') periods within the $36 \mathrm{~h}$ of study, though great differences amongst combinations were evident, especially in the sites 2 and 3 (Fig. 3). 
TABLE 1

Mean water values of alkalinity, $\mathrm{pH}$, temperature, dissolved inorganic carbon (DIC), dissolved oxygen (DO) and carbon dioxide saturation in Cima Lake from integrated light and dark periods within the 36 hours $(n=13)$ of study on March 5, 6 and 7 1997. Values between parentheses correspond to minimum and maximum determinations.

\begin{tabular}{|c|c|c|c|c|c|c|}
\hline Site & $\begin{array}{c}\text { Alkalinity } \\
\left(\mu \mathbf{E q}^{-1}\right)\end{array}$ & $\underset{\left(-\log \left[\mathbf{H}^{+}\right]\right)}{\mathbf{p H}}$ & $\begin{array}{c}\text { Temperature } \\
\left({ }^{\circ} \mathrm{C}\right)\end{array}$ & $\begin{array}{c}\text { DIC } \\
\left.(\mu \mathrm{mol} \mathrm{L})^{-1}\right)\end{array}$ & $\frac{\text { DO }}{\left(\mu \mathrm{mol} \mathrm{L} \mathrm{L}^{-1}\right)}$ & $\begin{array}{c}\mathrm{CO}_{2(\mathrm{aq})} \\
(\% \text { SAT. })\end{array}$ \\
\hline 1 & $\begin{array}{c}187 \\
(147-276)\end{array}$ & $\begin{array}{c}6.21 \\
(6.03-6.67)\end{array}$ & $\begin{array}{c}28.3 \\
(28.0-29.0)\end{array}$ & $\begin{array}{c}465 \\
(214-773)\end{array}$ & $\begin{array}{c}160 \\
(128-197)\end{array}$ & $\begin{array}{c}2,683 \\
(665-4,901)\end{array}$ \\
\hline 2 & $\begin{array}{c}190 \\
(158-285)\end{array}$ & $\begin{array}{c}6.66 \\
(6.53-6.95)\end{array}$ & $\begin{array}{c}28.3 \\
(28.0-29.0)\end{array}$ & $\begin{array}{c}285 \\
(203-467)\end{array}$ & $\begin{array}{c}217 \\
(201-232)\end{array}$ & $\begin{array}{c}914 \\
(385-1,749)\end{array}$ \\
\hline 3 & $\begin{array}{c}211 \\
(170-301)\end{array}$ & $\begin{array}{c}6.77 \\
(6.51-7.03)\end{array}$ & $\begin{array}{c}27.7 \\
(27.0-28.7)\end{array}$ & $\begin{array}{c}299 \\
(210-479)\end{array}$ & $\begin{array}{c}224 \\
(196-248)\end{array}$ & $\begin{array}{c}838 \\
(339-1,656)\end{array}$ \\
\hline
\end{tabular}

TABLE 2

Net fluxes of dissolved inorganic carbon (DIC) biologically fixed (negative values = production) or released (positive values $=$ mineralization) per light/dark periods in Cima Lake. Light and dark periods correspond to samplings in the day and night periods, respectively. Values are presented in $\mathrm{mmol} \mathrm{m}^{-2} 12 \mathrm{~h}^{-1}$. Every value is an integration from a total of four intervals of three hours each (yielding a total of 12 hours for every period).

\begin{tabular}{|c|c|c|c|c|}
\hline \multicolumn{2}{|c|}{ Site } & \multirow{2}{*}{ Period } & Date \\
\hline $\mathbf{1}$ & $\mathbf{2}$ & $\mathbf{3}$ & Dark & $3 / 5 / 97$ \\
\hline 503 & 112 & 216 & Light & $3 / 6 / 97$ \\
\hline-556 & -306 & -262 & Dark & $3 / 7 / 97$ \\
\hline 497 & 280 & 155 & \\
\hline
\end{tabular}

Therefore, DIC consumption extended from 53 to 59 , from 25 to 194 and from 46 to $107 \mathrm{mmol}$ $\mathrm{m}^{-2}$ day $^{-1}$, respectively, in sites 1,2 and 3 (Fig. 3a). These values are equivalent to a production that ranges from 0.3 to $2.3 \mathrm{~g} \mathrm{C} \mathrm{m}^{-2}$ day $^{-1}$ (Fig. $3 \mathrm{~b}$ ). Additionally, we might also present a single value of primary productivity for Cima Lake as a whole, as being a function of the arithmetic mean of values from combinations ' 1 ' and ' 2 '. In this case, estimate of net primary productivity would be equal to $80 \mathrm{mmol} \mathrm{DIC} \mathrm{m}^{-2}$ day $^{-1}$ (or $0.96 \mathrm{~g} \mathrm{C} \mathrm{m}^{-2}$ day $^{-1}$ synthesized). Overall, the observed differences indicate that, besides the treatment of data chosen, both spatial and temporal functions (short term in this study-case) may greatly affect the final evaluation of net carbon metabolism of Cima Lake.

Differences in daily rates of primary productivity in individual aquatic systems can, in fact, be enormous. Khondker \& Kabir (1995) found pri- mary productivity between 1.6 and $6.8 \mathrm{~g} \mathrm{C} \mathrm{m}^{-2}$ $\mathrm{day}^{-1}$ in a mesotrophic pond in Bangladesh from an annual study. Internal comparisons of our results from individual combinations ('combination 1' and 'combination 2', Fig. 3) showed relative differences that were similar to that from Khondker \& Kabir (1995). Depending on the combination (' 1 ' or ' 2 ') relative differences in the net primary productivity ranged from a factor of $\sim 1.2$ (site 1) to 7.8 (site 2) in Cima Lake system. It means that short-term primary productivity variations can rival those of long-term. Studying distribution of phytoplankton and photosynthesis in Lake Baringo (Kenya) Patterson \& Wilson (1995) interpreted diurnal cycle as dominating over any seasonal limnological cycle in the lake.

These observations suggest that careful is need to conceive and compare mean annual values of primary productivity in aquatic systems. 


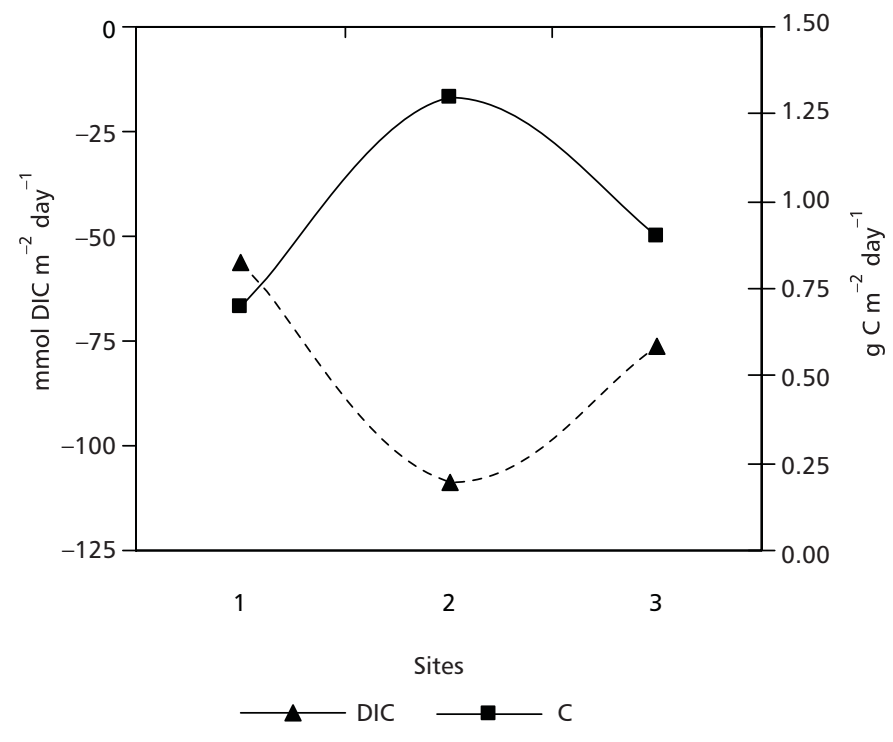

Fig. 2 - Spatial biologically mediated net flux of dissolved inorganic carbon (DIC) and its equivalence in carbon (C) synthesized (= organic carbon produced). Every value represents the arithmetic mean of dark/light and light/dark combined periods within the 36 hours of study (see text and Table 2).

In other words, annual estimates of primary productivity are potentially subject to great variations since they are build up from daily estimates, typically derived from a few set of measures and restricted to a short part of day. Yet, it should be kept in mind that the use of different methodologies for primary productivity calculations (e.g. ${ }^{14} \mathrm{C}, \mathrm{O}_{2}$, DIC, fluorescence) may represent an additional source of variation for inter comparisons between aquatic systems (not considered here).

In aquatic systems annual primary production usually ranges from virtually 0 (no net production) to $10^{3} \mathrm{~g} \mathrm{C} \mathrm{m}^{-2}$. Nevertheless, in coastal lagoons primary production typically ranges from 200 to $500 \mathrm{~g} \mathrm{C} \mathrm{m}^{-2} \mathrm{yr}^{-1}$ (Knoppers, 1994). Our data converted to annual net primary production clearly show a derivative case of short-term variation, with values ranging from a minimum of 110 to a maximum of $850 \mathrm{~g} \mathrm{C} \mathrm{m}^{-2} \mathrm{yr}^{-1}$. The amplitude of these values points out an unstable situation in the lacustrine system. This situation could be related to a dramatic input of 'new' waters from Imbé stream to Cima Lake because the period of sampling was preceded by a rainy week. It is supported by the fact that water level in Cima Lake raised $\sim 0.6 \mathrm{~m}$ in only one week (Souza, pers. commun.). In the field, however, clear sky and sunny days marked the weather. In such a situation solar radiation is abundant and nutrient is quite non-limiting to phytoplankton growth. The lake metabolism, therefore, seemed to be in a process of shifting from heterotrophic (indicated by $\mathrm{CO}_{2(\mathrm{aq})}$ supersaturation) to autotrophic function (evidenced by the net primary productivity). This likely explain the short-term primary productivity variation encountered in Cima Lake.

\section{CONCLUSIONS}

Our results are spatial and temporal limited because both they are site specific and the approach used here was based in a single short-term sampling. On the other hand, as sampling protocols are normally carried out in single days along the year, frequently based on monthly or biweekly frequencies, the final scientific build up and characterization of aquatic systems could be in part biased.

This is more critical if taken into account diurnal and/or daily variation, which are potentially 
greater than seasonal one, especially in tropical environments (Barbosa, 1997). Another concern is associated to spatial variation.

It is relevant from a systemic point of view since aquatic systems are characterized by connected and interdependent parts, to which forms a unity of system. Thus, for a reliable understanding of lake systems we suggest that sampling protocols should take into account the site-specific characteristics rather than following a mechanical or classical sampling approach. This is especially recommended in what concern natural great variations as typically happens with metabolism and other variables-like associated to water milieu.

Acknowledgments - We thank A. A. R. Gobo, A. C. O. Pessanha and W. P. Souza for collaborative efforts related to sampling and technical support within the 36 hours of our study. FENORTE, CNPq (CER 521965/98-9) and FINEP supported this work.
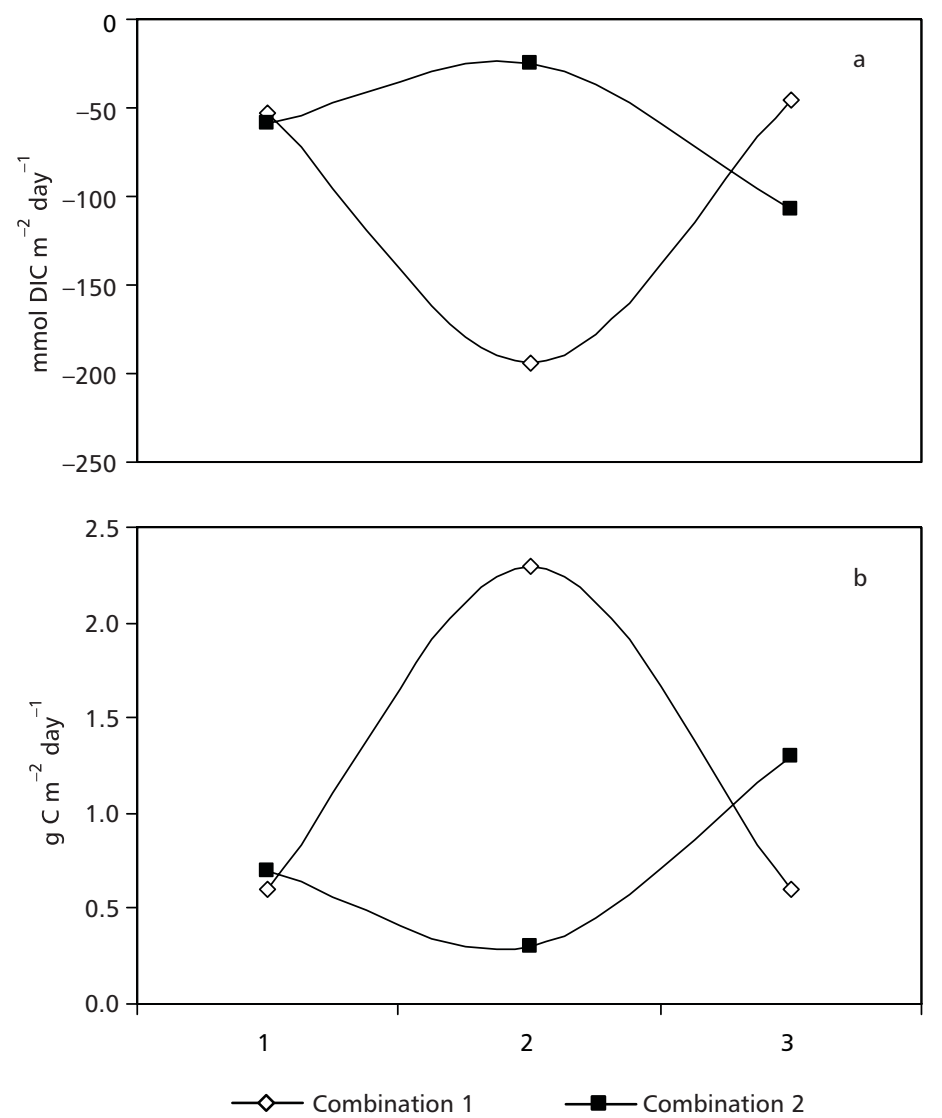

Fig. 3 - Like Fig. 2, but for individual combinations. 'Combination1' means combined dark/light periods from days 5 and 6, and 'Combination 2' means combined light/dark periods from days 6 and 7 on March 1997 (see Table 2). (a) Inorganic carbon flux; (b) equivalent carbon synthesized $(\mathrm{C}=$ organic carbon produced).

\section{REFERENCES}

ALMEIDA, M. G., 1998, Geoquímica de metais pesados na lagoa de Cima, RJ. Dissertação de Mestrado, Universidade Estadual do Norte Fluminense, Centro de Biociências e Biotecnologia, Campos dos Goytacazes (RJ), 113p.

ANDRADE, P. P., CARVALHO, C. C. V. \& REZENDE, C. E., 1998, Nota sobre a quantidade e qualidade de COP e COD em um sistema fluvio-lacustre no Norte Fluminense. R. Esc. Minas, 51: 62-66.
BARBOSA, F., 1997, The importance of diurnal cycles for the conservation and management of tropical waters: examples from the Rio Doce Valley Lakes system. In: J. G. Tundisi \& Y. Saijo (eds.), Limnological studies on the Rio Doce Valley Lakes, Brazil. University of São Paulo School of Engineering at São Carlos, São Carlos, pp. 449-456.

CALASANS, C. V. C., 1998, Origem e dinâmica da matéria orgânica em um sistema fluvio-lacustre da região Norte Fluminense. Tese de Doutorado, Universidade Estadual do Norte Fluminense, Centro de Biociências e Biotecnologia, Campos (RJ), 101p. 
CARMOUZE, J. P., KNOPPERS, B. \& VASCONCELOS, P., 1991, Metabolism of a subtropical brasilian lagoon. Biogeochemistry, 14: 129-148.

CARMOUZE, J. P., 1994, O metabolismo dos ecossistemas aquáticos: fundamentos teóricos, métodos de estudo e análises químicas. Ed. Edgard Blücher/SBL, São Paulo, $267 \mathrm{p}$.

del GIORGIO, P. A. \& PETERS, R. H., 1993, Balance between phytoplankton production and plankton respiration in lakes. Can. J. Fish. Aquat. Sci., 50: 282-289.

FALKOWSKI, P. G., 1994, The role of phytoplankton photosynthesis in global biogeochemical cycles. Photosynth. Res., 39: 235-258.

HANSELL, D. A., BATES, N. R. \& CARISON, C. A., 1997, Predominance of vertical loss of carbon from surface waters of the equatorial Pacific Ocean. Nature, 386: 59-61.

HEDGES, J. I., 1992, Global biogeochemical cycles: progress and problems. Mar. Chem., 39: 67-93.

HUSZAR, V. L. M. \& SILVA, L. H. S., 1992, Comunidades fitoplanctônicas de quatro lagoas costeiras do Norte do Estado do Rio de Janeiro, Brasil. Acta Limnol. Brasil., IV: 291-314.

KHONDKER, M. \& KABIR, M. A., 1995, Phytoplankton primary production in a mesotrophic pond in sub-tropical Bangladesh. Hydrobiologia, 304: 39-47.

KNOPPERS, B., 1994, Aquatic primary production in coastal lagoons. In: B. Kjerfve (ed.), Coastal Lagoon Processes, Chapter 9, Elsevier Science Publishers, Amsterdam.

LAMEGO, A. R., 1945, O homem e o brejo. Serviço Gráfico do IBGE, Rio de Janeiro, 204p.
PATTERSON, G. \& WILSON, K. K., 1995, The influence of the diel climatic cycle on the depth-time distribution of phytoplankton and photosynthesis in a shallow Equatorial lake (Lake Baringo, Kenya). Hydrobiologia, 304: $1-8$.

PEDROSA, P., CALASANS, C. V. C. \& REZENDE, C. E., 1999, Particulate and dissolved phases as indicators of limnological and ecophysiological spatial variation in Cima Lake system, Brazil: a case study. Hydrobiologia, 411(1-3): 89-101.

PRO-AGRO, 1975, Estudo das possibilidades da lagoa de Cima. Fundação Norte Fluminense de Desenvolvimento Regional, 36p.

RAVEN, J. A., 1993, Limits on growth rates. Nature, 361: 209-210.

RAVEN, J. A., 1994, Carbon fixation and carbon availability in marine phytoplankton. Photosynth. Res., 39: 259-273.

RIEBESELL, U., WOLF-GRADROW, D. A. \& SMETACEK, V., 1993, Carbon dioxide limitation of marine phytoplankton growth rates. Nature, 361: 249-251.

SOUZA, M. F. L. de \& COUTO, E. C. G., 1999, Short-term changes and longitudinal distribution of carbon metabolism in the Piauí River Estuary (Sergipe, Brazil). Rev. Brasil. Biol., 59: 195-202.

WAINRIGHT, S. C. \& FRY, B., 1994, Seasonal variation of the stable isotopic compositions of coastal marine plankton from Woods Hole, Massachusetts and Georges Bank. Estuaries, 17: 552-560.

WETZEL, R. G. \& LIKENS, G. E., 1991, Limnological analyses. Springer-Verlag, New York, 391p. 